\title{
DAMPAK BENCANA PADA SEKTOR PARIWISATA DI SITUS WARISAN BUDAYA DUNIA
}

Oleh :

Isni Wahyuningsih, SS

Staf Balai Konservasi Peninggalan Borobuudur

Beberapa waktu terakhir, Indonesia secara beruntun mengalami musibah baik karena faktor alam maupun faktor manusia, seperti banjir, gunung meletus, gempa, hingga tsunami. Memasuki bulan kedua tahun 2006, gunung Merapi yang terletak di perbatasan Jawa Tengah - Daerah Istimewa Yogyakarta dan termasuk teraktif di dunia tersebut dalam status siaga hingga awas. Ketika fokus perhatian pemerintah dan masyarakat tertuju ke status Merapi, bumi di Jawa Tengah Daerah Istimewa Yogyakarta dan sekitarnya bergoncang hebat di Sabtu pagi hari ke-27 bulan Mei, tepatnya pukul 5.57 WIB. Episentrum gempa berkekuatan 5,9 SR tersebut berkedalaman $10 \mathrm{~km}$ di lokasi 7,96 LS : 110,46 BT arah selatan Yogyakarta (sesar Opak - Oya). ( Tempo edisi 5-11 Juni 2006)

Selain menelan korban jiwa lebih dari 6.000 orang tewas, 50.000 luka-luka, dan 70.000 ribu bangunan roboh/rusak berat, termasuk benda cagar budaya. Kawasan Jawa Tengah dan Daerah Istimewa Yogyakarta terkenal kaya akan bangunan cagar budaya warisan nenek moyang, beberapa diantaranya telah diakui sebagai warisan budaya dunia, seperti Candi Borobudur, Candi Prambanan dan Situs Prasejarah Sangiran yang telah menjadi ikon pariwisata Indonesia. Dalam bencana ini, nasib menyedihkan menimpa Candi Prambanan, yang mengalami kerusakan cukup parah, begitu pula dengan benda cagar budaya disekitarnya seperti Candi Ijo, Candi Sewu, Candi Plaosan, Kraton Kasultanan Yogyakarta, Tamansari, Kotagede, dan Makam Imogiri.

Kondisi Situs Warisan Budaya Dunia Pasca Gempa 5,9 SR dan Status Awas Merapi

Dalam bencana alam ini Candi Borobudur di Magelang sclamat dari bahava gempa. Namun dalam beberapa mingeru sempat dihuani abu vulkanik dari Gunung Nerapi Mbu Merapi paling bansak meneclimuti bagian timur, utara, dan selatan (andi Borobudur. I lal tersebut dikarenakan hembusan abu datang dari wah tmour. Darl hasil penclitian, abu whank tersebut tidak herpengaruh pada hatuan candi, karena kadar asamnvalemah, pt Insathanva 6,5. Inalisal ab. BKPB
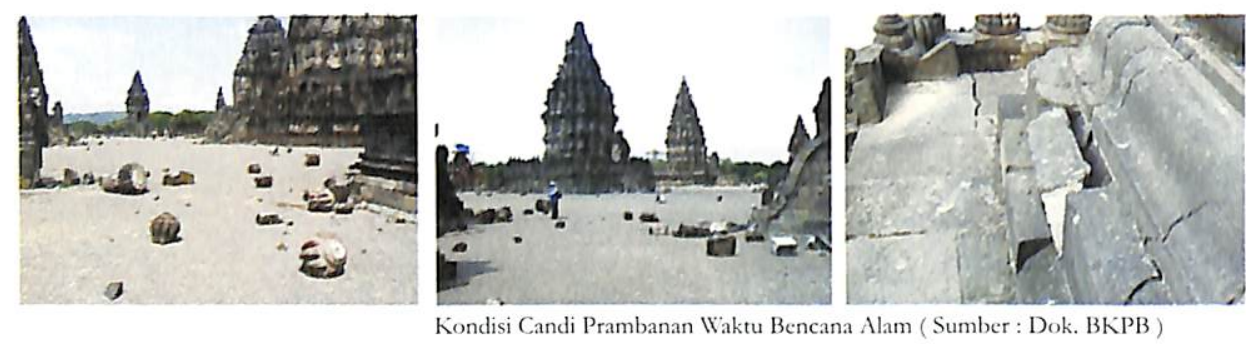

Sementara itu Kompleks Candi Prambanan dan candi-candi di sekitarnya mengalami kerusakan, seperti Candi Plaosan, Ratu Boko, Candi Sewu dan Candi Ijo. Pada Kompleks Candi Prambanan, 3 candi utama yakni Brahma, Siwa, dan Wisnu semuanya rusak, termasuk candi pendamping, yaitu Angsa, Nandi dan Garuda.

Tetapi yang paling parah kerusakannya adalah Candi Brahma, mahkota kemuncaknya runtuh, teras pintu masuk ke ruang candi ambrol menutupi pintu candi. Candi Syiwa yang bangunannya paling besar, retak di berbagai tempat bahkan tubuh bagian tengah Candi Syiwa bergeser beberapa centimeter. Begitu pula Candi Angsa, Nandi, dan Garuda, bagian puncaknya miring dan kemuncaknya terancam jatuh. Batu-batu dari reruntuhan candi berserakan di pelataran. Garupa halaman satu sisi barat, gapura halaman tiga sisi selatan mengalami kerusakan berat. Walaupun begitu Kompleks Candi Prambanan tetap terbuka untuk kegiatan kepariwisataan. Selama proses restorasi objek wisata, Prambanan tidak ditutup, justru diharapkan wisatawan bisa menyaksikan langsung proses restorasi tersebut. Untuk keamanan, pengunjung hanya boleh melihat candi dariluar pagar teralis.

Situs Sangiran vang terletak di Sragen, Jawa Tengah dan jauh dari episentrum gempa tidak mengalami kerusakan pada bencana gempa dan crupsi Merapi. Bencana belum jua berakhir melanda tanah air, gempa mengenearig beberapa dacrah, seperti di Pangandaran yang disusul dengan tsunami, crupsi gunung berapi, sampai luapan lumpur panas di Sidoarjo vang belum berhenti sampai sekarang.

Pariwisata di Situs Warisan Budaya Dunia

Banyaknya jumlah wisatawan yang berkunjung di suatu obyek tujuan wisata erat kaitannya dengan tingkat

Grafik 1: Jumlah Pengunjung Gandi Borobudur tahun 1984 - 2005

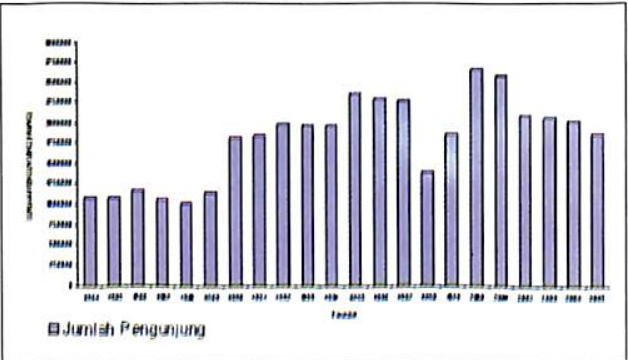

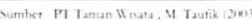
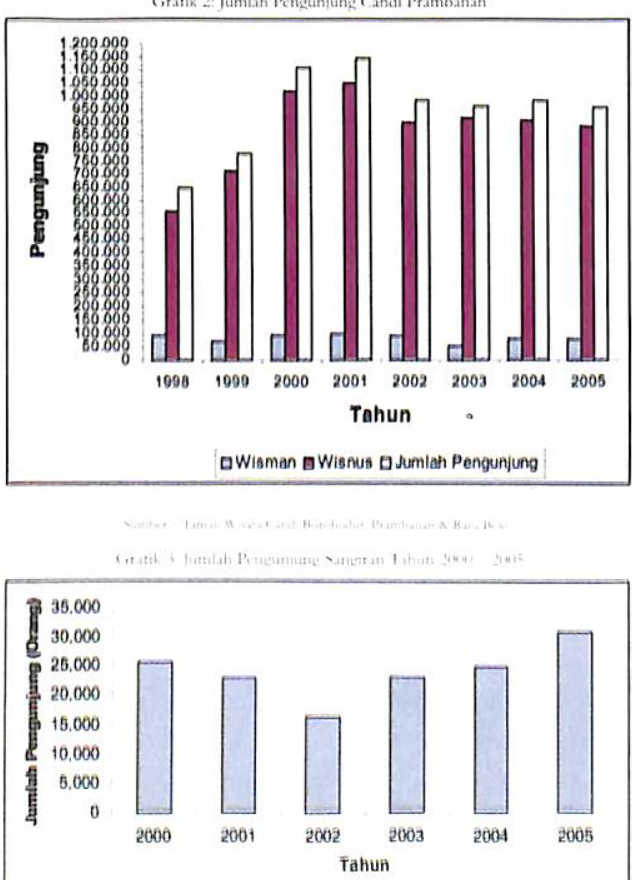

๑ Jumlah Pengunjung 
keamanan dan situasi politik pada waktu itu. Pengunjung di ketiga situs warisan dunia tersebut mempunyai komposisi terbesar vaitu wisatawan nusantara yang pangsa pasar utama berasal dari daerah Jawa Timur, Jawa Barat dan Jawa Tengah, serta didominasi oleh kalangan pelajar. Pangsa pasar wisatawan Jepang, Taiwan, Prancis, Jerman, dan Belanda mendominasi wisatawan mancanegara.

Selama satu tahun terdapat waktu-waktu yang menjadi puncak kunjungan di Candi Borobudur, Candi Prambanan, dan Sangiran yaitu pada bulan Juni, Juli, dan Desember serta pada hari libur besar seperti Idul Fitri, Tahun Baru, dan Hari Natal. Selain hari-hari tersebut di atas, terdapat juga hari di mana terjadi peningkatan jumlah wisatawan yaitu hari Minggu sepanjang tahun.

\section{Kondisi Pariwisata di Situs Warisan Budaya Dunia Pasca Bencana}

Bisnis sektor pariwisata merupakan aktivitas yang sangat sensitif, rentan terhadap hal-hal yang berkaitan dengan kondisi sosial ekonomi, keamanan, kesehatan, dan situasi politik dari suatu negara atau wilayah tujuan wisata, terutama kalangan wisatawan mancanegara. Gambaran citra dunia pariwisata Indonesia beberapa tahun belakangan tampak menurun, terutama sejak musibah beruntun yang menerpa sejumlah daerah di tanah air, baik yang disebabkan oleh faktor manusia maupun alam.

Musibah peristiwa bom di Legian Bali (2002) yang menewaskan ratusan turis asing, pengeboman di beberapa wilayah di tanah air (2003-2005). Bencana alam tsunami di Aceh (2004), masalah yang terkait dengan kesehatan (mewabahnya SARS \& flu burung). Kondisi pasca gempa dan erupsi Merapi tahun 2006 ditambah kondisi ekonomi yang terpuruk dan kenaikan bahan bakar minyak, menyebabkan wisatawan turun drastis.

Pada tahun 2006, pengunjung Candi Borobudur di bulan Januari mencapai 209.071 (204.106 wisnus; 4.965 wisman). Pada bulan Mei turun menjadi 83.233 (77.785 wisnus; 5.448 wisman). Pada bulan Juni - Juli yang biasanya melonjak, karena masa liburan sekolah, menjadi turun karena adanya bencana alam gempa dan erupsi Merapi sebesar 82.533 orang (79.913 wisnus; 2.620 wisman). Pengunjung terus menurun di bulan JuniSeptember. Pada bulan ()ktober saat

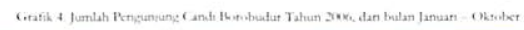

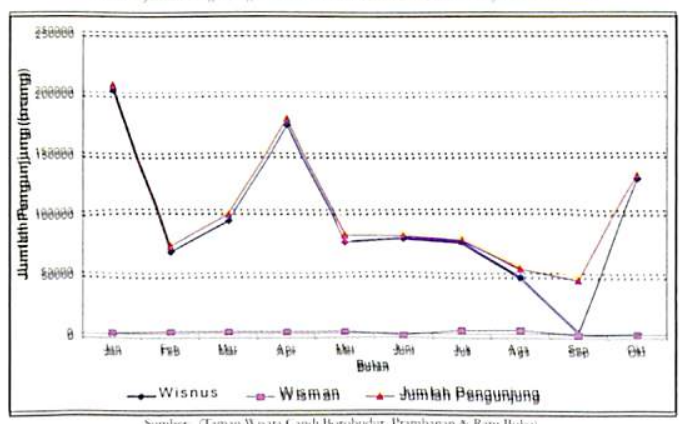

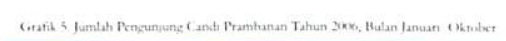

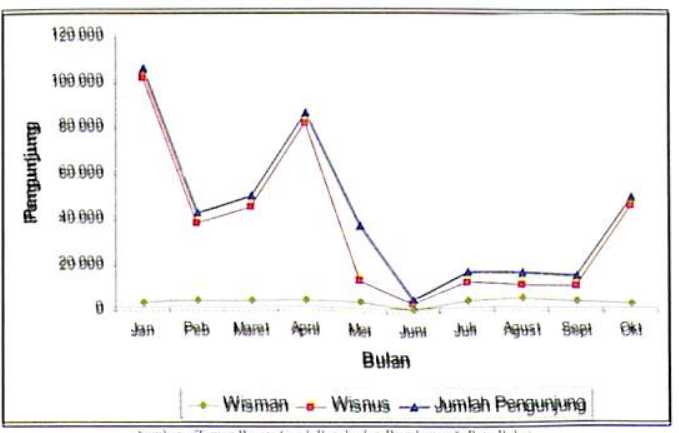

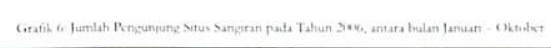

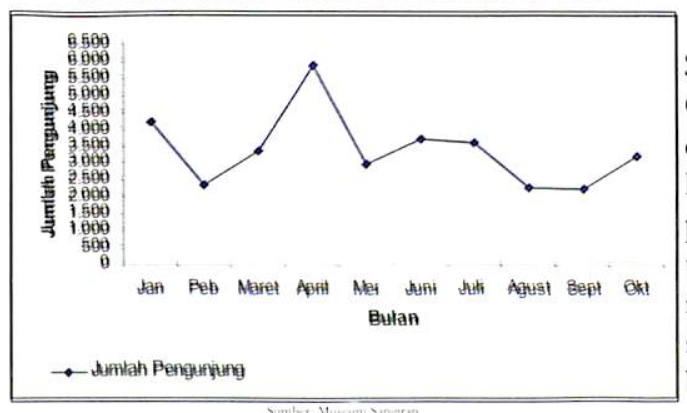

liburan Hari Raya, yang biasanya melonjak hanya 134.777 orang (130.652 wis nus; 4.125 wisman).

Di Candi Prambanan wisatawan pada bulan Januari tahun 2006 (liburan sekolah) mencapai 106.112 (102.595 wisnus; 3.517 wisman), menurun dibulan berikutnya. Pada bulan Mei turun drastis menjadi 37.747 orang, dan semakin menyedihkan pada pasca gempa dan erupsi Merapi, hanya 5.473 orang $(793$ wisman; 4.680 wisnus). Hal tersebut disebabkan kondisi candi-candi di kompleks Prambanan dalam kondisi rusak berat, sangat riskan bagi keamanan pengunjung, schingga pengunjung hanya boleh melihat dari kejauhan tidak bisa masuk ke dalam candi sebelum dilakukan restorasi.

Bencana yang beruntun melanda dengan banyak korban jiwa dan harta benda, menjadikan berwisata menjadi kebutuhan terkesampingkan. Taktor keamanan dan kenramanan (ketakutan/kekuatiran) bagi yang tidak terlanda bencana, menjadikan mereka

mengurungkan niat berwisata, seperti di Jawa Timur setelah bencana Lapindo Brantas, sekolah-sekolah dianjurkan tidak berwisata ke arah barat.

Pada tahun 2006, pengunjung di situs Sangiran mengalami peningkatan, dari bulan Januari - Oktober saja bahkan melampaui jumlah di tahun sebelumnya sebesar 31.816 orang. Pada bulan Januari (4.225 orang) dan April (5.866 orang) merupakan jumlah terbanyak, karena terdapat liburan sekolah. Pada bulan-bulan pasca gempa Juni (3.699) - Juli (3.605) saat libur sekolah mengalami kenaikan.

Hal tersebut disebabkan situs ini malah menerima limpahan pengunjung yang sebelumnya bertujuan wisata ke Yogyakarta. Kenaikan jumlah tahuntahun terakhir tersebut, antara lain disebabkan oleh Pemda setempat memasukkan Sangiran sebagai muatan lokal (wajib kunjung). Untuk wisatawan mancanegara yang berkunjung di situs ini berkisar 20-45 orang setiap bulannya, namun sejak terjadinya bom Bali, mengalami penurunan.

Jumlah pengunjung di situs Sangiran bila dibandingkan dengan situs Candi Borobudur dan Candi Prambanan dapat disebabkan oleh kondisi masyarakat kita (tingkat pendidikan/sistem pendidikan) masih kurang menjunjung tinggi ilmu pengetahuan, lebih mengutamakan rekreasi untuk bersenangsenang daripada untuk sesuatu yang bersifat belajar/keilmuan, seperti masyarakat yang kebanyakan apatis terhadap museum; Kurang gencarnya promosi dan pengelolaan belum maksimal ; Aksesibilitas yang kurang memadai menuju Situs Sangiran.

Ketika bencana bertubi menerpa tanah air terutama di dacrah sekitar situs warisan budaya dunia, dampak terasa pada sektor pariwisata di antaranya pada aspek:

Ekonomi . Menurunnya pengunjung di situs warisan budaya dunia tersebut, otomatis mengurangi pemasukan bagi: Pengelola, dalam hal ini PT. Taman Wisata Candi Borobudur Prambanan dan Ratu Boko. Target untuk meraup laba 2 milyar tiap tahunnya gagal dicapai. Dalam kondisi yang kembang kempis, berpengaruh pada managemen perusahaan, yang berimbas pada kescjahteraan karvawan Berkurangnya pemasukan negara/pemerintah; lasa perantara pariwisata : Biro perialanan. perhotelan penginapan mengalame penurunan tamu; Massarakat sckitar situs warisan budasa dunia lang sebagian besar meniadi pedagane 


\section{Hasil Studi}

cinderamata, rumah/warung makan, guide, fotografer, tukang parkir, tukang becak/andong dan sebagainya. Menurut pengakuan mereka keadaan sepi pengunjung ini terasa sejak kenaikan BBM tahun lalu dan semakin diperparah oleh bencana alam gempa bumi Mei 2006. Penghasilan mereka sangat jauh merosot sampai 50\% lebih jika dibandingkan tahun-tahun sebelumnya. Pengrajin cinderamata seperti di Pajangan, Imogiri, Kotagede, turut merasakan dampaknya.

Budaya. Rusak atau musnahnya bangunan monumental, benda cagar budaya yang tiada ternilai harganya, warisan anak cucu kita, yang sangat berguna bagi ilmu pengetahuan, arkeologi, sejarah dan budaya bangsa kita.

Sosial. Dampak positif: tumbuhnya solidaritas sosial yang tinggi terhadap sesama, seperti para pengasong, penjual cinderamata, guide, dan juru potret di Candi Prambanan. Mereka saling berbagi, ketika ada yang dapat rejeki, sedangkan yang lain belum, mereka saling berbagi pendapatan. Dampak negatif: trauma bagi pelaku pariwisata ataupun wisatawan pada hari 27 Mei 2006 mengalami sendiri ataupun menjadi korban; Tekanan ekonomi bisa menimbulkan dapak meningkatnya kriminalitas di sekitar kawasan wisata.

Bertumpu dari hal yang telah disampaikan di atas, maka menjadi tantangan bagi kita untuk bangkit dan mengambil langkahlangkah agar :

Benda-berda cagar budaya yang rusak ataupun musnah, seyogyanya di data secara rinci sebaik mungkin,serta didokumentasikan sebaik-baiknya (oleh pihak yang berwenang)

Sedangkan untuk memulihkan kondisi pada sektor pariwisata dapat dilakukan langkah-langkah antara lain : Meningkatkan promosi dan layanan, memperbanyak perwakilan biro wisata di luar negeri; Mengundang wartawan dari luar negeri untuk meliput obyek dan daya tarik wisata; Mengubah strategi promosi, pengembangan wisata minat khusus; Aksesibilitas ke daerah tujuan wisata utama dipermudah, sepertipembukaan jalur-jalur penerbangan langsung ke daerah tujuan wisata; Menindak lanjuti Deklarasi Borobudur tidak cuma sekedar deklarasi tanpa realisasi. Untuk bangkit dari keterpurukan, semua pihak harus bangkit dan bekerja sama baik pemerintah maupun pelaku pariwisata dan masyarakat. $\times$

\section{Daftar Pustaka}

Daud Aris Tanudirjo, "Kualitas Penyajian Warisan Budaya kepada Masyarakat: Studi Kasus Managemen Sumberdaya Budaya Candi Borobudur", Laporan Penelitian. PAU, Studi Sosial, UGM, 1993-1994.

Jonathan Sarwono, Metode Penelitian Kuantitatif dan Kualitatif, (Yogyakarta: Graha Ilmu, 2006).

Maulana Ibrahim, Kompleks Candi Prambanan dari Masa ke Masa, (Direktorat Perlindungan dan Pembinaan Peninggalan Sejarah dan Purbakala, Jakarta, 1996).

Muhammad Taufik dkk, Evaluasi Pendukung Wisata di Jalur Pengunjung Kompleks Candi Borobudur, (Balai Konservasi Peninggalan Borobudur, 2005).

M. Taufik, Minimalisasi Dampak Negatif Pemanfaatan Candi Borobudur Sebagai Obyek Wisata. ( Tesis studi Arkeologi UGM, 2003)

Spillane, James, Ekonomi Pariwisata: Sejarah dan Prospeknya. (Yogyakarta: Kanisius, 1987).

Undang-undang No. 9 Tahun 1990. Objek dan Daya Tarik Wisata. (Departemen Pariwisata, Pos dan Telekomunikasi, 1990).

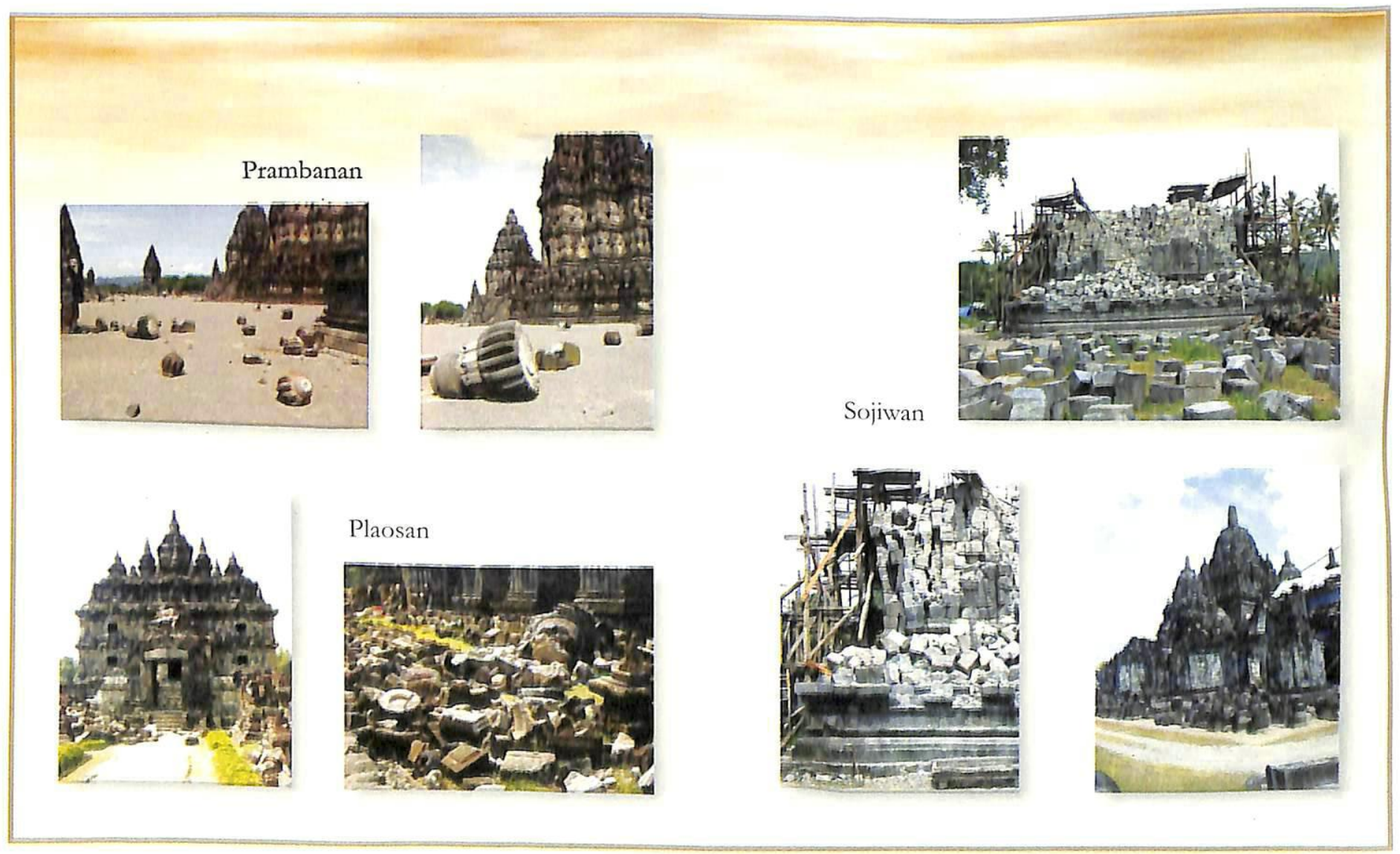

